\title{
Tungstate (VI) Sorption on Hematite: An in situ ATR-FTIR Probe on the Mechanism
}

\author{
Sudipta Rakshit ${ }^{\mathrm{a}^{*}}$, Bryan Sallman $^{\mathrm{a}}$, Athénais Davantés ${ }^{\mathrm{b}}$, and Grégory Lefèvre ${ }^{\mathrm{b}}$ \\ ${ }^{a}$ Department of Agricultural and Environmental Sciences, Tennessee State University, \\ 3500 John A. Merritt Blvd., Nashville, Tennessee 37209-1561 \\ ${ }^{b}$ PSL Research University, Chimie Paris Tech-CNRS, Institut de Recherche de Chimie Paris, \\ 75005 Paris, France. \\ *Corresponding author. Tel.: +1 615-963-6058; Fax: +1 615-963-5436. E-mail address: \\ srakshit@tnstate.edu
}

Key Words: Polytungstate, sorption, hematite, Infrared. 


\begin{abstract}
Owing to the suspected toxicity and carcinogenicity of tungstate (VI) oxyanions [i.e. mono tungstate and several polytungstate, generally represented by W(VI)], the environmental fate of W (VI) has been widely studied. Sorption is regarded as a major mechanism by which W (VI) species are retained in the solid/ water interface. Iron (hydr )oxides have been considered important environmental sinks for W (VI) species. Here we report sorption mechanisms of W (VI) on a common iron oxide mineral-hematite under environmentally relevant solution properties using in situ attenuated total reflectance Fourier transform infrared (ATR-FTIR) spectroscopic probes. Initial W (VI) loadings varied from $10-200 \mu \mathrm{M}$ at fixed $\mathrm{pH}$ values ranged from 4.6-8.1. For $\mathrm{pH}$ envelope $(\mathrm{pHs}=4.6,5.0,5.5,6.0,6.5,7.5$, and 8.1) experiments, fixed $\mathrm{W}$ (VI) concentrations (i.e. $10 \& 200 \mu \mathrm{M}$ ) were used to understand the effects of $\mathrm{pH}$. The results indicated that at acidic $\mathrm{pH}$ values $(\mathrm{pH}<6.0)$ the sorbed polytungstate surface species are prominent at $200 \mu \mathrm{M}$ initial W (VI) conc. The $\mathrm{pH}$ envelop experiments revealed that sorbed polytungstates can be present even at lower initial $\mathrm{W}(\mathrm{VI})$ conc. (i.e. $10 \mu \mathrm{M}$ ) at $\mathrm{pH}$ values $<5.5$. Overall, our in situ ATR-FTIR experiments indicated that W (VI) forms inner-sphere type bonds on hematite surface and the strength of the interaction increases with decreasing $\mathrm{pH}$. In addition, initial W (VI) concentration affected the sorption mechanisms of W (VI) on hematite. Our study will aid the molecular level understanding of $\mathrm{W}(\mathrm{VI})$ retention on iron oxide surfaces.
\end{abstract}




\section{Introduction}

Recently tungsten (W) has invoked considerable attention in the scientific community due to its suspected link to the childhood leukemia cluster in Fallon, NV; Sierra Vista, AR and Elk Grove, CA (Koutosospyros et al., 2006). Although the Center of Disease Control's (CDC) investigation did not reveal a conclusive evidence about the link between childhood leukemia cluster and $\mathrm{W}$, the concerns about the $\mathrm{W}$ as a toxic element triggered many studies assessing the effects of W exposure to human, animal, plant, and to overall ecological health (Strigul et al., 2005, 2010; Thomas et al., 2009; Ringelberg et al., 2009; Johnson et al., 2009; Kelly et al., 2013; Laulicht et al., 2015). With their in vivo experiments involving wild mice, Kelly et al. (2012) concluded that chronic W exposure with a conc. of 15-200 mg L $\mathrm{L}^{-1}$ and for a period of 16 weeks could increase DNA damage, alter B-cell development and ultimately could act as a tumor promoter. The carcinogenic potential of $\mathrm{W}$ to the human bronchial epithelial cell line was reported as well (Laulicht et al., 2015). Strigul et al. (2005) noticed that $95 \%$ of soil bacteria died after 3 months of incubation with $\mathrm{W}$ powder.

The environmental provenance of $\mathrm{W}$ can be caused both by anthropogenic activities and by natural processes solubilizing W compounds (Seiler et al., 2005; Johannesson et al., 2013). Seiler et al. (2005) attributed the elevated conc. of $\mathrm{W}\left(0.27-742 \mu \mathrm{g} \mathrm{L} \mathrm{L}^{-1}\right)$, found in ground water samples of the aquifers in Carson Desert, NV, to the dissolution of the W-bearing mineral in the Carson River watershed and to the upwelling geothermal waters. Alternatively, Hsu et al. (2011) reported that water and sediment contamination form the treated effluents of the semiconductor manufacturing industry in Taiwan. The unique physical and chemical properties of W prompted its frequent use in industrial and domestic applications (Strigul, 2005). Major industrial and 
domestic applications of $\mathrm{W}$ include tungsten-cemented carbides, metal wires, turbine blades, high temperature lubricants, catalysts, incandescent lamp filaments, television sets, heat sinks, golf clubs, fishing weights, and hunting ammunitions (Koutosospyros et al., 2006). Tungsten (W) has been used as a substitute for lead $(\mathrm{Pb})$ in hunting and recreational shooting after the ban on Pb shot in USA and Norway for hunting waterfowl (Fisher et a., 2006; Thomas et al., 2009). In fact, the US Army's pollution prevention initiative, the Green Armament Technology (GAT) program, proposed the use of $\mathrm{W}$ in low caliber ammunition (Koutosospyros et al., 2006; Johannesson et al., 2013). The overall worldwide production of $\mathrm{W}$ in 2001 was reported to be 44,200 metric tons, $83 \%$ of which was from China (Shedd, 2001).

The environmental chemistry of $\mathrm{W}$ is complex. The most stable oxidation state of $\mathrm{W}$ is +6 in surface and near surface aqueous environments (Hur and Reeder, 2016). In this oxidation state, several mono-and polymeric oxyanions with a generic name tungstate (e.g. mono tungstate- $\mathrm{WO}_{4}{ }^{2-}$, paratungstate $\mathrm{A}-\mathrm{W}_{7} \mathrm{O}_{24}{ }^{6-}$, paratungstate $\mathrm{B}-\mathrm{H}_{2} \mathrm{~W}_{12} \mathrm{O}_{42}{ }^{10-}, \alpha$-metatungstate$\mathrm{H}_{2} \mathrm{~W}_{12} \mathrm{O}_{40}{ }^{6-}$ ) exist under various solution conditions (Ogundipe et al., 2009; Hur and Reeder, 2016). Generally, monomeric non-protonated tungstate species $\left(\mathrm{WO}_{4}{ }^{2-}\right)$ prevail at neutral to alkaline conditions, whereas acidic $\mathrm{pH}$ values promote polymerization leading to formation of poly-tungstate species (Cruywagen and van der Merwe, 1987; Shijun et al., 1998; Ogundipe et al., 2009; Cruywagen, 2000; Gustafsson, 2003; Davantés et al., 2015; Davantés and Lef evre, 2015; Hur and Reeder; 2016). However, this general consensus is based on limited data on the solution speciation of $\mathrm{W}(\mathrm{VI})$. There are many unclear aspects of solution speciation of W (VI). First, the conversion of mono-tungstate $\left(\mathrm{WO}_{4}{ }^{2-}\right)$ to some of the polymeric forms may take as long as 8 months (Smith and Patrick, 2000). Therefore, use of true thermodynamic equilibrium conditions for short-term experiments may be complex. Second, in all of the studies, the solution 
speciation was conducted at very high initial concentrations of W (VI) due to either lack of sensitivity of the currently available analytical instrumentations or the laboratory methods [e.g. 0.5-123 mM in the titration data of Cruywagen and van der Merwe, (1987); 0.5 M in Shijun et al. 1998; 3 M in Smith and Patrick, (2000); and 2 mM in Hur and Reeder, (2016)]. Since W (VI) is known to polymerize at higher conc., extrapolating these solution speciation data to the $\mu \mathrm{M}$ level conc. should be done with caution.

In contrast, sorbed species of W (VI) have been successfully characterized in recent research work by Hur and Reeder, (2016) and Davantés et al. (2015) with initial W (VI) concentrations as low as $5 \mu \mathrm{M}$ and $10 \mu \mathrm{M}$ using EXAFS and in situ ATR-FTIR spectroscopic tools, respectively. Davantés et al. (2015) characterized W (VI) sorption complexes with layered double hydroxide (LDH) using in situ ATR-FTIR scans in the $\mathrm{pH}$ range of 5-9 and found that polytungstate ions electrostatically sorbed to $\mathrm{LDH}$ and the main species is paratungstate $\mathrm{A}$ $\left(\mathrm{W}_{7} \mathrm{O}_{24}{ }^{6-}\right.$ ). Hur and Reeder, (2016) conducted an analysis of $5 \mu \mathrm{M}$ sorbed-W (VI) on boehmite using $\mathrm{W} \mathrm{L}_{1}$ and $\mathrm{L}_{3}$-edge XANES and compared the results with model compounds to find that the sorption samples at both $\mathrm{pH}$ values (4 and 8 ) contained octahedrally coordinated W (VI) with some distortion in structure (distorted octahedral configuration). It is known that monotungstate has tetrahedral coordination and polytunsgate has octahedral coordination (Panagiotou et al., 2009; Davantés and Lefèvre, 2015). The results at higher concentrations were similar, i.e., unlike the solution speciation, only the poly tungstate species existed as the surface bound species at both low (4) and high (8) $\mathrm{pH}$ values. However, the authors acknowledged that due to the lack of sensitivity of the method used to detect all the surface complexes, it was possible that there were some tetrahedral tungstate (mono tungstate, $\mathrm{WO}_{4}{ }^{2-}$ ) present as well. The authors 
reported that the $\mathrm{W}(\mathrm{VI})$ sorption on boehmite was strong inner-sphere type at lower $\mathrm{pH}$ and became less strong as the $\mathrm{pH}$ was increased.

Since sorption is the main retention process by which W (VI) can be immobilized in the environment, a thorough understanding of the sorption mechanism is important to predict W (VI) mobility and to remediate dissolved W (VI) in the environment (Gustafsson, 2003; Hur and Reeder, 2016). Iron (hydr)oxides are an important sink in the environment for many oxyanions and have already been reported to possess high affinity for W (VI) (Gustafsson, 2003; Xu et al., 2006, 2009; Lorenz, 2009; Lorenz et al., 2011; Kashiwabara et al., 2013; Davantés and Lefévre, 2015; Sun and Bostick, 2015). However, a detailed mechanistic study using in situ surface sensitive spectroscopic tools such as ATR-FTIR is lacking. There are several advantages of using in situ ATR-FTIR techniques over other spectroscopic tools in that this technique is noninvasive, highly sensitive to small structural changes, and the results are obtained in real time(Hind et al., 2001; Lefèvre, 2004; Hug and Bahnemann, 2006; Elzinga and Sparks, 2007; Zhang and Peak, 2007). The ex-situ FTIR requires high loading of the sample (i.e. mM to M level) when compared to the in situ one, in which data can be collected at low loadings (i.e. to the $\mu \mathrm{M}$ level). In addition, the sample drying may cause structural alterations of surface complexes that may favor surface speciation that is not representative of actual in situ conditions (Elzinga and Sparks, 2007). To date no studies have been published to analyze the surface interaction mechanisms of $\mathrm{W}(\mathrm{VI})$ on hematite surface under various environmentally relevant solution properties. Hence, the main objective of this study is to probe surface interaction mechanism of $\mathrm{W}(\mathrm{VI})$ on hematite across an environmentally relevant $\mathrm{pH}$ range (4.6-8.1) and initial W (VI) conc. (10-200 $\mu \mathrm{M})$. 


\section{Materials \& Methods}

\subsection{Reagent and materials}

Hematite was prepared according to the procedures described in Sugimoto et al. (1993)

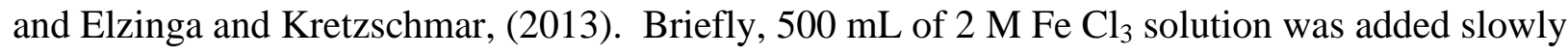
over a period of $5 \mathrm{~min}$ to a continuously stirred $500 \mathrm{~mL}$ solution of $5.4 \mathrm{M} \mathrm{NaOH}$. The resulting gel was aged in a sealed Pyrex glass bottle at $101^{\circ} \mathrm{C}$ for 8 days. After cooling to room temperature, the product was washed with Milli-Q water $(18.2 \mathrm{M} \Omega \mathrm{cm})$ until the electrical conductivity was $<5 \mu \mathrm{S} \mathrm{cm}^{-1}$. The resulting suspension was then freeze-dried. The mineral identity was confirmed using X-ray diffraction (Rigaku, Woodlands, TX). The mineral was stored in a dry place under room temperature. Sodium tungstate $\left(\mathrm{Na}_{2} \mathrm{WO}_{4}, 2 \mathrm{H}_{2} \mathrm{O}\right)$ was purchased from Sigma Aldrich (Grass Lake, MI) and used as received.

\subsection{In situ ATR-FTIR Experiments}

To evaluate the molecular interaction of W (VI) with hematite, in situ ATR-FTIR experiments were carried out with a Perkin Elmer Frontier Infrared spectrometer equipped with a liquid $\mathrm{N}_{2}$ cooled MCT-A (mercury cadmium telluride) detector and an optics compartment purged with $\mathrm{CO}_{2}$ - and $\mathrm{H}_{2} \mathrm{O}$-free air delivered by a Balston- Parker air purger. The flow cell consists of a rectangular holder into which a horizontal $45^{\circ} \mathrm{ZnSe}$ ATR crystal is attached (Pike Technologies, Madison, WI), coated with a thin film of mineral substrate $(\sim 2.5 \mathrm{mg})$, prepared by overnight drying of $500 \mu \mathrm{L}$ mineral suspension in water evenly spread across the crystal surface, and a top portion that seals the flow cell. The flow cell is installed on the ATR sample stage of the IR spectrometer and connected to an Ar-purged reaction vessel containing $500 \mathrm{~mL}$ background electrolyte solution $(0.01 \mathrm{M} \mathrm{NaCl})$ adjusted to desired $\mathrm{pH}$ values. A peristaltic pump (Watson Marlow 400, Falmouth, UK) was used to circulate the solution in the reaction vessel to the flow cell at a rate of $2 \mathrm{~mL} \mathrm{~min}^{-1}$. The content of the reaction vessel was 
continuously stirred with a magnetic stir bar to ensure even mixing. The $\mathrm{pH}$ was monitored throughout the experiment and readjusted when necessary using $0.1 \mathrm{M} \mathrm{NaOH}$ or $\mathrm{HCl}$. The adsorption isotherm/ loading experiments were conducted at various $\mathrm{pH}$ values between 5-8 using the flow cell set up described above and in other studies (Elzinga and Sparks, 2007; Rakshit et al., 2013ab). This type of in situ flow cell experiments using ZnSe HATR (Horizontal ATR) crystal is noted for the first time in the environmental science related literature by Hug and Sulzberger, (1994). Hug, (1997), in another study, noted that at a very low conc. of sulfate, the IR signal enhancement for the sulfate sorption on hematite coated HATR cell was $\sim 33 \%$ more than the uncoated HATR cell (Hug, 1997), thereby indicating the IR signal is caused by the sorption phenomenon. In our study, we collected similar IR spectra of dissolved W (VI) in hematite uncoated HATR cell and compared with that of sorbed W (VI) on hematite coated HATR cell under same solution properties (i.e. ionic strength, initial W (VI) conc. and pH). We found negligible signal for dissolved W(VI) (Supporting documents Figure S1 \& 2). Therefore, we assumed the IR bands associated with the sorption experiments are mainly arising due to $\mathrm{W}$ (VI) binding on hematite- a very similar inference used by Hug, (1997) and other researchers conducting in situ ATR-FTIR experiments for sorption process.

Each experiment was started by a preliminary equilibration step, in which the background electrolyte solution was pumped through the flow cell at a particular $\mathrm{pH}$ value and flow rate (2 $\mathrm{mL} \min ^{-1}$ ) for approximately $2 \mathrm{~h}$. During the equilibration period, background spectra were recorded frequently. All other spectra were collected as a ratio against the background spectrum. The adsorption isotherm / loading experiments were initiated at fixed $\mathrm{pH}$ values $(\mathrm{pHs}=5.05$, $6.01,7.05$, and 8.1 ) by introducing an appropriate volume of aliquot of freshly prepared $\mathrm{W}(\mathrm{VI})$ stock solution (prepared from $\mathrm{Na}_{2} \mathrm{WO}_{4}, 2 \mathrm{H}_{2} \mathrm{O}$, Sigma Aldrich) through injection in the reaction 
vessel to achieve a desired solution concentration. The adsorption of W (VI) onto the mineral substrate film was monitored through the characteristic IR absorbances in the 1400 to $700 \mathrm{~cm}^{-1}$ spectral range (Davantés et al., 2015; Davantés and Lefévre, 2015). Intensities of the IR bands were noted from the collected spectra. When no further increase of the intensities of the IR bands of W (VI) were found, it was assumed that the sorption reaction had reached equilibrium and the final scan of adsorbed W (VI) was collected. After that the W (VI) concentration was raised to the next level and allowed to attain sorption equilibrium. This procedure was repeated to obtain $\mathrm{W}(\mathrm{VI})$ isotherms in the range of $10-200 \mu \mathrm{M}$.

To test the effects of $\mathrm{pH}$ on W (VI) sorption on hematite, the initial equilibrium step with the background electrolyte solution was followed at a fixed $\mathrm{pH}(8.1)$. Since W (VI) is known to polymerize at lower $\mathrm{pH}(<6)$ and higher concentrations, the $\mathrm{pH}$ envelope experiment was started at higher $\mathrm{pH}$ value (i.e. 8.1) and lowest possible $\mathrm{W}$ (VI) conc. (i.e. $10 \mu \mathrm{M}$ for discernable spectra). The $\mathrm{pH}$ envelope experiment was initiated by introducing appropriate volume of aliquot of freshly prepared W (VI) stock solution through injection in the reaction vessel to achieve a solution concentration of $10 \mu \mathrm{M}$ at a fixed $\mathrm{pH}$ value. After the equilibration was reached, the $\mathrm{pH}$ was lowered to a value less than the previous one and a new equilibrium was established and the final scan of sorbed-W (VI) spectra was be recorded. This process was repeated to record the spectra until a $\mathrm{pH}$ value of 4.6 was reached.

Collected infrared (IR) spectra were corrected for background by linearizing the baseline in the range $700-1400 \mathrm{~cm}^{-1}$. All spectra, other than the ones in difference spectra, were normalized to the highest peak near $920 \mathrm{~cm}^{-1}$. Difference spectra were obtained by subtracting the background corrected non-normalized spectra following the procedures of Elzinga and Sparks, (2007). Difference spectra were plotted in between the parent spectra for comparisons. 


\section{Results \& Discussions}

\subsection{Analysis of W (VI) loading on hematite deposit at fixed pH}

The infrared (IR) spectra of W (VI) sorption on hematite at fixed $\mathrm{pH}$ values were shown in Figures 1 A, B, C, and D. Spectra were collected with a W (VI) initial conc. range of 10-200 $\mu \mathrm{M}$ (i.e. 1.83-367 $\mathrm{mg} \mathrm{W} \mathrm{L}^{-1}$ ). The corresponding difference spectra were obtained by subtracting the background corrected raw spectrum for each conc. set (Figures $2 \mathrm{~A}_{1}, \mathrm{~B}_{1}, \mathrm{C}_{1}$, and $D_{1}$ ). The concentration ranges used in our study are consistent with the current spectroscopic studies on W (VI) sorption mechanisms and environmentally relevant detected levels of W in the terrestrial and aquatic systems (Koutosospyros et al., 2006; Davantés et al., 2015; Hur and Reeder, 2016). To gain insights on the W (VI) binding mechanism on hematite, the spectra can be inspected in two different ways. First, at fixed pH values, the IR bands of sorbed W (VI)hematite at various $\mathrm{W}(\mathrm{VI})$ initial conc. $(10-200 \mu \mathrm{M})$ can be compared to understand if there were any changes in the IR peak shapes or the positions when initial concentrations of W (VI) had been increased. A corresponding difference spectrum between highest and lowest initial $\mathrm{W}$ (VI) can clarify the changes in IR bands upon increasing conc. as well. Use of difference spectra in interpretations of IR bands in sorption mechanisms is widely accepted in literature (Goyne et al., 2005; Zhang and Peak, 2007; Elzinga and Sparks, 2007; Boer et al., 2009; Elzinga and Kretzschmar, 2013). Second, collected spectra can also be compared across the $\mathrm{pH}$ values studied (i.e. pHs 5.05-8.1) for any specific change in the IR bands with variations of $\mathrm{pH}$ values.

Inspection of the IR bands of sorbed W (VI)-hematite spectra collected at $\mathrm{pH} 8.1$ indicate a strong peak at $929 \mathrm{~cm}^{-1}$ and a broken band at $833 \mathrm{~cm}^{-1}$ for all the initial conc. of W (VI) (i.e. 10-200 $\mu \mathrm{M}$ ). It should be noted that all the spectra in Figures 1A, B, C, and D were normalized; therefore, no comparisons based on the intensities among the spectra could be made. However, the difference spectra (Figures $2 \mathrm{~A}_{1}, \mathrm{~B}_{1}, \mathrm{C}_{1}, \mathrm{D}_{1}$ ) were obtained by subtracting background 
corrected non-normalized spectra. Hence, the difference spectra can be used to note any increase in the intensities of the peaks. Interestingly, the difference spectra $(200-10 \mu \mathrm{M})$ at $\mathrm{pH} 8.1$

(Figure $2 \mathrm{~A}_{1}$ ) reveals that the IR band at $929 \mathrm{~cm}^{-1}$ has increased in intensity with the increase in initial W (VI) conc. This indicates the amount of W (VI) sorbed on hematite increased with increasing initial conc. of $\mathrm{W}$ (VI) from 10 to $200 \mu \mathrm{M}$. However, no discernable change in peak shapes is observed at $929 \mathrm{~cm}^{-1}$, indicating that $\mathrm{W}(\mathrm{VI})$ binding relevant to this peak position most likely did not change with increasing initial W (VI) conc. Generally, symmetric stretching modes of $\mathrm{W}-\mathrm{O}$ bonds in $\mathrm{WO}_{4}$ unit of $\mathrm{W}(\mathrm{VI})$ were assigned to wavenumbers bet ween 930-960 $\mathrm{cm}^{-1}$ in the literature (Zorina and Syritso, 1972; Charton et al., 2002; Tomaszewicz et al., 2009; Kumar and Mohanta, 2011; Tribalis et al., 2014; Davantés and Lefévre, 2015). Therefore, the appearance of a strong IR band at $929 \mathrm{~cm}^{-1}$ with increasing initial conc. of $\mathrm{W}$ (VI) is representative of the binding of $\mathrm{W}(\mathrm{VI})$ on the hematite surface through the $\mathrm{O}$ atom. For all other $\mathrm{pH}$ values (see Figures 1B, C, and D) a very similar feature can be noticed.

The second broad IR band at wavenumber $\sim 833 \mathrm{~cm}^{-1}$ for the sorbed W (VI)-hematite spectra collected at $\mathrm{pH} 8.1$ (Figure 1A) is most likely due to the antisymmetric W-O vibrations (Charton et al., 2002; Kumar and Mohanta, 2011; Tribalis et al., 2014). The difference spectra for $\mathrm{pH} 8.1$ (Figure $2 \mathrm{~A}_{1}$ ) highlights some changes in the shape of the IR peak at $833 \mathrm{~cm}^{-1}$ for 10 $\mu \mathrm{M}$ sorbed $\mathrm{W}(\mathrm{VI})$-hematite spectra compared to that of $200 \mu \mathrm{M}$. This suggests that some changes in the W (VI) binding on hematite relevant to the antisymmetric stretching band of W-O most likely occurred upon increasing W (VI) initial conc. from 10 to $200 \mu \mathrm{M}$ at pH 8.1. Analyses of other spectra collected at $\mathrm{pH}$ values from 7-5.05 indicate that the peak at $833 \mathrm{~cm}^{-1}$ became much stronger as the $\mathrm{pH}$ value is decreased. At $\mathrm{pH} 5.05$, the IR band around 830-870 $\mathrm{cm}^{-1}$ indicated a strong but broad peak (Figure 1D). Interestingly, the W-O-W stretching 
vibrations, which are characteristics of polymeric tungstate species, can appear $\sim 875 \mathrm{~cm}^{-1}$ (Tribalis et al., 2014). Therefore, the strong but broad IR band in the sorbed W (VI)-hematite spectra (at $\mathrm{pH}$ 5.05) is most likely due to the presence of two combined peaks from the antisymmetric stretching band of $\mathrm{W}-\mathrm{O}$ bond $\left(\sim 833 \mathrm{~cm}^{-1}\right)$ and the stretching vibrations of $\mathrm{W}-\mathrm{O}-\mathrm{W}$ bonds $\left(\sim 875 \mathrm{~cm}^{-1}\right)$. Owing to close proximity of $\mathrm{W}-\mathrm{O}$ antisymmetric vibration $\left(833 \mathrm{~cm}^{-1}\right)$ and W-O-W stretching vibration $\left(875 \mathrm{~cm}^{-1}\right)$, the separation between these two IR bands may be ambiguous when the IR band is broad (Figures 1A-D). However, the difference spectra can clarify any change of peak shapes and intensities in this region.

The difference spectra between the highest $(200 \mu \mathrm{M})$ and lowest $(10 \mu \mathrm{M}) \mathrm{W}$ (VI) loadings at this $\mathrm{pH}$ value resulted in an IR band in the $873 \mathrm{~cm}^{-1}$ position (Figure $2 \mathrm{D}_{1}$ ), thereby suggesting the presence of polytungstate surface species (Charton et al., 2002; Tribalis et al., 2014). Therefore, at $\mathrm{pH} 5.05$, upon increasing initial W (VI) conc. from 10 to $200 \mu \mathrm{M}$, a polytungstate surface species was formed (Figure 2 $\mathrm{D}_{1}$ ). In fact, Tribalis et al. (2014), in their in situ Raman study of oxo-tungsten (VI) species deposition on titania surface, assigned a $875 \mathrm{~cm}^{-1}$ band to the $\mathrm{W}-\mathrm{O}-\mathrm{W}$ stretching vibrations of two polymeric tungstate species, such as $\mathrm{W}_{7} \mathrm{O}_{24}{ }^{6-}$ and $\mathrm{HW}_{7} \mathrm{O}_{24}{ }^{5-}$. Interestingly, the difference spectra for $\mathrm{pH}$ 6.01(Figure $2 \mathrm{C}_{1}$ ) indicated formation of an IR band at $872 \mathrm{~cm}^{-1}$. This suggests that the polymeric $\mathrm{W}(\mathrm{VI})$ species started forming at $\mathrm{pH} 6.01$. These results are consistent with the known solution speciation of $\mathrm{W}(\mathrm{VI})$, in which $\mathrm{W}(\mathrm{VI})$ is present as a monomeric species at $\mathrm{pH}$ values (>6) and below that polymeric species begin to form (Cruywagen and van der Merwe, 1987; Smith and Patrick, 2000; Panagiotou et al., 2009; Davantés et al., 2015; Hur and Reeder, 2016). However, the speciation of W (VI) seems to vary with change in conc. at a fixed $\mathrm{pH}$ value as well (Hur and Reeder, 2016). This is consistent with our finding that IR bands corresponding to the polytungstate surface species resulted in the 
sorbed W (VI)-hematite spectra at pH 5.05, in which W (VI) initial conc. was $200 \mu \mathrm{M}$. A similar IR band was absent for a lower initial W (VI) conc. (Figures 1D, 2D $\mathrm{D}_{1}$ ), indicating the absence of polymeric $\mathrm{W}$ (VI) species at $10 \mu \mathrm{M}$ initial W (VI) conc. However, due to the broad nature of the IR band near this region, the presence of polytungstate surface species at $10 \mu \mathrm{M}$ cannot be overruled. From the difference spectra at Figure 2D1, we can only verify that the presence of polytungstate surface species becomes prominent when the conc. is increased to $200 \mu \mathrm{M}$. In the next section, in which the IR data collected in $\mathrm{pH}$ envelop experiments (conducted at both 10 and $200 \mu \mathrm{M}$ initial W (VI) conc.) were discussed, a clearer understanding about this phenomenon may be revealed.

The IR bands in the regions $1000-1200 \mathrm{~cm}^{-1}$ constitutes an interesting feature, which is most likely hinting at the formation of polytungstate surface species. Several IR peaks (1285, $1288,1191,1171,1064$, and $1064 \mathrm{~cm}^{-1}$ ) appear in this region at $\mathrm{pH} 6.01$, and 5.05 are absent at higher pH values. Kumar and Mohanta, (2011) noted W-OH vibrational bands near $1041 \mathrm{~cm}^{-1}$. Multiple IR peaks close to this region may represent multiple W-OH vibrational bands corresponding to either poly tungstate surface species or H-bonding interactions. Similar features are completely absent at higher $\mathrm{pH}$ values (i.e. at 7.05 and 8.1).

In summary, the loading or isotherm experiments conducted at fixed $\mathrm{pH}$ values indicate that $\mathrm{W}$ (VI) sorption increased with increasing conc. at all $\mathrm{pH}$ values as noted by the strong IR band $\sim 929 \mathrm{~cm}^{-1}$. The formation of polytungstate surface species is more prominent at higher initial W (VI) conc. $(\sim 200 \mu \mathrm{M})$ at $\mathrm{pH}$ values 6.0 and 5.01 .

\subsection{Analysis of pH envelop}

Background corrected normalized IR spectra for $\mathrm{pH}$ envelop experiments conducted at two fixed conc. of $\mathrm{W}$ (VI) $(10 \& 200 \mu \mathrm{M})$ were shown in Figures 3A and 3B, respectively. The 
corresponding difference spectra were depicted in the Figures $3 \mathrm{~A}_{1}$ and $3 \mathrm{~B}_{1}$. These IR spectra would help understand if change in the $\mathrm{pH}$ value affected the sorption mechanism/ surface complexation of $\mathrm{W}(\mathrm{VI})$ on hematite. The difference spectra for $10 \mu \mathrm{M} \mathrm{W}$ (VI) revealed several key features (Figure $3 \mathrm{~A}_{1}$ ). First, as the $\mathrm{pH}$ is lowered from 8.1 to 4.6 gradually with a 0.5 unit difference, the intensity of the W-O stretching band $\left(\sim 947 \mathrm{~cm}^{-1}\right)$ increased consistently (Figure 3 A1). This reflects that the amount of W (VI) sorption increased with decreasing $\mathrm{pH}$. Also strengthening of this IR-band most likely represents the inner-sphere nature of the interaction being more prominent at lower $\mathrm{pH}$ values. Second, the broad IR band near $830-880 \mathrm{~cm}^{-1}$ became well-formed and intense as the $\mathrm{pH}$ value was gradually decreased from 8.1 to 4.6. We found in our inspection of IR band in the previous section that the broad peak around this region could be a combination of the W-O antisymmetric stretching band $\left(\sim 833 \mathrm{~cm}^{-1}\right)$ and $\mathrm{W}-\mathrm{O}-\mathrm{W}$ stretching vibration $\left(\sim 874 \mathrm{~cm}^{-1}\right)$. In fact, the difference spectra of pHs $(4.6-8.1),(5.0-8.1)$, and (5.5-8.1) clearly showed an IR peak near $874 \mathrm{~cm}^{-1}$ (Figure $3 \mathrm{~A}_{1}$ ). Therefore, the presence of polytungstate surface species even at a lower initial conc. of $\mathrm{W}(\mathrm{VI})(10 \mu \mathrm{M})$ can be predicted at $\mathrm{pH}$ values 4.6, 5.0, and 5.5. This result is consistent with the W (VI) sorption study on boehmite by Hur and Reeder, (2016), in which the authors reported the presence of polytungstate surface species at acidic $\mathrm{pH}$ values at a very low $\mathrm{W}(\mathrm{VI})$ conc.

The difference spectra collected for the $\mathrm{pH}$ envelope experiments carried out at higher initial W (VI) conc. $(200 \mu \mathrm{M})$ showed that the intensity of the W-O stretching band $\left(\sim 947 \mathrm{~cm}^{-1}\right)$ increased consistently with decreasing $\mathrm{pH}$ (Figure $\left.3 \mathrm{~B}_{1}\right)$, thereby indicating the amount of sorption and the strength of the sorption interaction (i.e. inner-sphere vs. outer-sphere bonds) increased consistently. This feature of the IR band at this position is very similar to that of the difference spectra collected at lower W (VI) conc.(i.e. $10 \mu \mathrm{M})$. The contrasting features of the 
IR bands of the $\mathrm{pH}$ envelope experiments carried out at $200 \mu \mathrm{M}$ initial W (VI) conc. as compared to that of $10 \mu \mathrm{M}$ initial $\mathrm{W}$ (VI) conc. arise in the band position $877 \mathrm{~cm}^{-1}$. A careful inspection reveals that the peaks at $877 \mathrm{~cm}^{-1}$ band position in the various difference spectra [i.e. $\mathrm{pH}$ (4.6-8.1), (5.0-8.1), and (5.5-8.1)] are much sharper and intense for $\mathrm{W}(\mathrm{VI}) \sim 200 \mu \mathrm{M}$ than that of $\mathrm{W}(\mathrm{VI}) \sim 10 \mu \mathrm{M}$. This most likely suggests that at $200 \mu \mathrm{M}$ intial $\mathrm{W}$ (VI) conc. the amount and the extent of the surface interactions of polytungstate species with hematite are greater than that of $\mathrm{W}(\mathrm{VI}) \sim 10 \mu \mathrm{M}$.

\section{Conclusion}

This study reports for the first time about detailed surface chemical interactions of tungstate with hematite under environmentally relevant solution properties using in situ spectroscopic techniques (i.e. ATR-FTIR). The results indicate that W (VI) sorbs strongly on hematite surface. The amount and extent of sorption, revealed by the strong IR bands in the range $929-947 \mathrm{~cm}^{-1}$, increased with decreasing $\mathrm{pH}$. The formation of sorbed polytungstate surface species is more prominent at lower $\mathrm{pH}$ values (i.e. 4.6, 5.0, 5.5, and 6.0) and higher initial W (VI) conc. (i.e. $200 \mu \mathrm{M}$ ). However, at $\mathrm{pH}$ values 4.6, 5.0, and 5.5, although not prominent, some evidences for the existence of sorbed polytungstate surface species can be found in the IR bands near $870-880 \mathrm{~cm}^{-1}$ region. More work using reference compounds are needed to isolate the exact polytungstate surface species sorbed on hematite. Our study will help enhance the molecular level understanding of the tungstate retention mechanisms on oxide surfaces.

\section{Acknowledgement}

The authors acknowledge the Evans Allen funds from USDA-NIFA and start up grants from Tennessee State University for providing support for this research work. 


\section{References}

Borer, P., Hug, S.J., Sulzberger, B., Kraemer, S.M., Kretzschmar, R., 2009. ATR-FTIR spectroscopic study of the adsorption of desferrioxamine B and aerobactin to the surface of lepidocrocite ( $\gamma-\mathrm{FeOOH})$. Geochim. Cosmochim. Ac. 73, 4661-4672.

Charton, P., Gengembre, L., Armand, P., 2002. TeO2-WO3 glasses: Infrared, XPS, and XANES structural characterizations. J. Solid State Chem. 168, 175-183.

Cruywagen, J.J., 2000. Protonation, oligomerization, and condensation reactions of vanadate (V), molybdate (VI), and tungstate (VI). Adv. Inrog. Chem. 49, 127-182.

Cruywagen, J.J., van der Merwe, I.F.J., 1987. Tungsten (VI) equilibria: A potentiometric and calorimetric investigation. J. Chem. Soc. Dalton Trans. 7, 1701-1705.

Davantés, A., Costa, D., Lefévre, G., 2015. Infrared study of ( poly) tungstate ions in solution and sorbed into layered double hydroxides: Vibrational calculations and in situ analysis. J. Phys. Chem. C 119, 12356-12364.

Davantés, A., Lefévre, G., 2015. In situ characterization of (poly) molybdate and (poly) tungstate ions sorbed onto iron (hydr)oxides by ATR-FTIR spectroscopy. Eur. Phys. J. Special Topics 224, 1977-1983.

Elzinga, E.J., Kretzschmar, R., 2013. In situ ATR-FTIR spectroscopic analysis of the coadsorption of orthophosphate and Cd (II) onto hematite. Geochim. Cosmochim. Ac. 117, 53-64.

Elzinga, E.J., Sparks, D.L., 2007. Phosphate adsorption onto hematite: An in situ ATR-FTIR investigation of the effects of $\mathrm{pH}$ and loading level on the mode of phosphate surface complexation. J. Collid Interf. Sci. 308, 53-70. 
Fisher, F.J., Pain, D.J., and Thomas, V.G., 2006. A review of lead poisoning from ammunition sources in terrestrial birds. Biol. Conserv. 131, 421-432.

Goyne, K.W., Chorover, J., Kubicki, J.D., Zimmerman, A.R., Brantley, S.L., 2005. Sorption of antibiotic ofloxacin to mesoporous and nonporous alumina and silica. J. Colloid Interf. Sci. $283,160-170$.

Gustafsson, J.P., 2003. Modelling molybdate and tungstate adsorption to ferrihydrite. Chem. Geol. 200, 105-115.

Hind, A.R., Bhargava, S.K., McKinnon, A., 2001. At the solid / liquid interface: FTIR/ ATR the tool of choice. Adv. Colloid Interfac. 93, 91-114.

Hsu, S-C., Hsieh, H-L., Chen, C-P., Tseng, C-M., Huang, S-C., Huang, C-H., Huang, Y-T., Radashevsky, V., and Lin, S-H., 2011. Tungsten and other heavy metal contamination in aquatic environment from semiconductor manufacturing. J. Hazard. Mater. 189, 193-202.

Hug, S.J., Bahnemann, D., 2006. Infrared spectra of oxalate, malonate, and succinate adsorbed on the aqueous surface rutile, anatase, and lepidocrocite measured with in situ ATRFTIR. J. Electron spectrosc. 150, 208-219.

Hug, S.J., Sulzberger, B., 1994. In situ Fourier transform infrared spectroscopic evidence for the formation of several different surface complex of oxalate on $\mathrm{TiO} 2$ in the aqueous phase. Langmuir 10, 3587-3597.

Hug, S.J. In situ Fourier transform infrared measurements of sulfate adsorption on hematite in aqueous solutions. J. Colloid Interf. Sci. 188, 415-422.

Hur, H., Reeder, R.J., 2016. Tungstate sorption mechanisms on boehmite: Systematic uptake studies and X-ray absorption spectroscopy analysis. J. Colloid Interf. Sci. 461, 249-260. 
Johannesson, K.H., Dave, H.B., Mohajerin, T.J., Datta, S., 2013. Controls on tungsten concentrations in groundwater flow systems: The role of adsorption, aquifer sediment $\mathrm{Fe}$ (III) oxide / oxyhydroxide content, and thiotungstate formation. Chem. Geol. 351, 76-94. Johnson, D.R., Inouye, L.S., Bednar, A.J., Clarke, J.U., Winfield, L.E., Boyd, R.E., Ang, C.Y., 2009. Tungsten bioavailability and toxicity in sunflowers (Helianthus annuus). J. Land Contam. Reclam. 17, 141-151.

Kashiwabara, T., Takahashi, Y., Marcus, M.A., Urga, T., Tanida, H., Terada, Y., Usui, A., 2013. Tungsten species in natural ferromanganese oxides related to its different behavior from molybdenum in oxic ocean. Geochim. Cosmochim. Ac. 106, 364-378.

Kelly, A.D.R., Lemaire, M., Young, Y.K., Eustache, J.H., Guilbert, C., Molina, M.F., Mann, K.K., 2013. In vivo tungsten exposure alters B-cell development and increases DNA damage in murine bone marrow. Toxicological Sciences 131, 434-446.

Koutsospyros, A., Braida, W., Christodoulatos, C., D. Dermatas, Strigul, N., 2006. A review of tungsten: From environmental obscurity to scrutiny. J. Hazard. Mater. 136, 1-19.

Kumar, V.B., Mohanta, D., 2011. Formation of nanoscale tungsten oxide structures and colouration characteristics. Bull. Mater. Sci. 34, 435-442.

Laulitch, F., Brocato, J., Cartularo, L., Vaughan, J. Wu, F. Kluz, T. Sun, H. Oksuz, B.A., Shen, S., Peana, M., Medici, S., Zoroddu, M.A., Costa., M., 2015. Tungsten-induced carcinogenesis in human bronchial epithelial cells. Toxicol. Appl. Pharm. 288, 33-39.

Lefévre, G., 2004. In situ Fourier-transform infrared spectroscopy studies of inorganic ions adsorption on metal oxides and hydroxides. Adv. Colloid Interfac. 107, 109-123.

Lorenz, E.A., 2009. Role of speciation in tungstate sorption on iron oxyhydroxides: A spectroscopic study. MS thesis, Stoney Brook University. 
Lorenz, E.A., Hur, H., Reeder, R.J., 2011. Tungstate polymerization and its role in sorption on iron and aluminum oxyhydroxides. Mineral. Mag. 75 (3), 1391.

Ogundipe, A., Pavlov, J., Braida, W., Koutsospyros, A., Sen, G., Christodoulatos, C., and O'Connor, G., 2009. Evaluation of analytical methods to address tungsten speciation. Global Nest J 11, 308-317.

Panagiotou, G.D., Petsi, T., Bourikas, K., Kordulis, C., Lycourghiotis, A., 2009. The interfacial chemistry of the impregnation step involved in the preparation of tungsten (VI) supported titania catalysis. J. Cat. 262, 266-279.

Rakshit, S., Elzinga, E. J. Sarkar, D., Datta, R.., 2013a. In Situ ATR-FTIR study of oxytetracycline sorption on nano-magnetite. J. Environ. Qual. 42, 822-827

Rakshit, S., Sarkar, D. Elzinga, E.J. Punamiya, P. Datta, R.., 2013b. Mechanisms of ciprofloxacin removal by nano-sized magnetite. J. Hazard. Mater. 246-247, 221-226.

Ringelberg, D.B., C.M. Reynolds, Winfield, L.E., Inouye, L.S. Johnson, D.R., Bednar. A.J., 2009. Tungsten effects on microbial community structure and activity in a Soil. J. Environ. Qual. 38, 103-110.

Seiler, R.L., Stollenwerk, K.G., Garbarino., J.R., 2005. Factors controlling tungsten concentrations in groundwater, Carson desert, Nevada. Appl. Geochem. 20, 423-441.

Shedd, K.B. 2001. Tungsten, in: U.S. Geological Survey Minerals Yearbook, 80, 1-6.

Shijun, L., Qiyuan, C., Pingmin, Z., Songqin, L., 1998. Raman spectral study on isopolytungstates in aqueous solution. Trans. Nonferorrous Met. Soc. China. 4, 688-692.

Smith, B.J., Patrick, V.A., 2000. Quantitative determination of sodium metatungstate speciation by 183W N.M.R. spectroscopy. Aus. J. Chem. 53, 965-970. 
Strigul, N., Koutsospyros, A., Arienti, P., Christodoulatos, C., Dermatas, D., Braida, W., 2005. Effects of tungsten on environmental systems. Chemosphere 61, 248-258.

Strigul, N., Koutsospyros, A., Christodoulatos, C., 2010. Tungsten speciation and toxicity: Acute toxicity of mono-and poly-tungstates to fish. Ecotoxicology and Environmental Safety 73, 164-171.

Sugimoto, T., Sakata, K., Muramatsu, A., 1993. Formation mechanism of monodisperse pseudocubic $\alpha-\mathrm{Fe}_{2} \mathrm{O}_{3}$ particles from condensed ferric hydroxide gel. J. Colloid Interf. Sci. $159,372-382$.

Sun, J., Bostick, B.C., 2015. Effects of tungstate polymerization on tungsten (VI) adsorption on ferrihydrite. Chem. Geol. 417, 21-31.

Thomas, V.G., Roberts, M.J., and Harrison, P.T.C., 2009. Assessment of the environmental toxicity and carcinogenicity of tungsten-based shot. Ecotoxicology and Environmental Safety 72, 1031-1037.

Tomaszewicz, E., Kaczmarek, S.M., Fuks, H., 2009. New cadmium and rare earth metal tungstates with the scheelite type structure. J. Rare Earth 27, 569-573.

Tribalis, A., Panagiotou, G.D., Tsilomelekis, G., Kalampounias, A.G., Bourikas, K., Kordulis, C., Boghosian, S., Lycourghiotis, A., 2014. J. Phys. Chem. C 118, 11319-11332.

Xu, N., Christodoulatos, C., Braida, W., 2006. Adsorption of molybdate and tetrathiomolybdate onto pyrite and goethite:effect of $\mathrm{pH}$ and competitive anions. Chemosphere 62, 17261735.

Xu, N., Christodoulatos, C., Braida, W., 2009. Competitive sorption of tungstate, molybdate, and phosphate mixtures onto goethite. 
Zhang, G.Y., Peak, D., 2007. Studies of Cd (II)-sulfate interactions at the goethite-water interface by ATR-FTIR spectroscopy. Geochim. Cosmochim. Ac. 71, 2158-2169. Zorina, M.L., Syristo, L.F., 1972. IR spectra and structures of tungstates. Zhurnal Prikladnoi Spektroskopi 16 (6), 1043-1045.

\section{FIGURE CAPTION}

Figure 1. ATR-FTIR spectra of sorbed W (VI) on hematite at fixed $\mathrm{pH}$ values of A) 8.1, B) 7.05, C) 6.01 , D) 5.05 with increasing initial $\mathrm{W}(\mathrm{VI})$ loadings of $10,25,50,100, \& 200 \mu \mathrm{M}$ and fixed ionic strength (I) of $0.01 \mathrm{M} \mathrm{NaCl}$. The symbol [W] $]_{\mathrm{i}}$ represents initial conc. of added W (VI). The arrow denotes the direction of increasing conc. in the spectra.

Figure 2. ATR-FTIR difference spectra collected at the highest W (VI) conc. and those collected at lowest W (VI) conc. at fixed pH values of $\mathbf{A}_{1}$ ) 8.1, $\mathbf{B}_{1}$ ) 7.05, $\mathbf{C}_{1}$ ) 6.01, $\mathbf{D}_{1}$ ) 5.05. For visual guidance, each difference spectrum was plotted in between the highest (i.e. $200 \mu \mathrm{M}$ ) and lowest (i.e. $10 \mu \mathrm{M}) \mathrm{W}(\mathrm{VI})$ loadings. 
Figure 3. ATR-FTIR spectra of sorbed W (VI) on hematite in the $\mathrm{pH}$ range of 4.6-8.1 at fixed ionic strength $\mathrm{I}=0.01 \mathrm{M} \mathrm{NaCl}$ and initial $\mathrm{W}$ (VI) conc. A) $10 \mu \mathrm{M}$ and B) $200 \mu \mathrm{M}$ were plotted with corresponding difference spectra at fixed W (VI) conc. $\left.\mathbf{A}_{\mathbf{1}}\right) 10 \mu \mathrm{M}$ and $\left.\mathbf{B}_{1}\right) 200 \mu \mathrm{M}$ to indicate the growth of the W (VI) surface complex with decreasing $\mathrm{pH}$ values. 
Figure 1
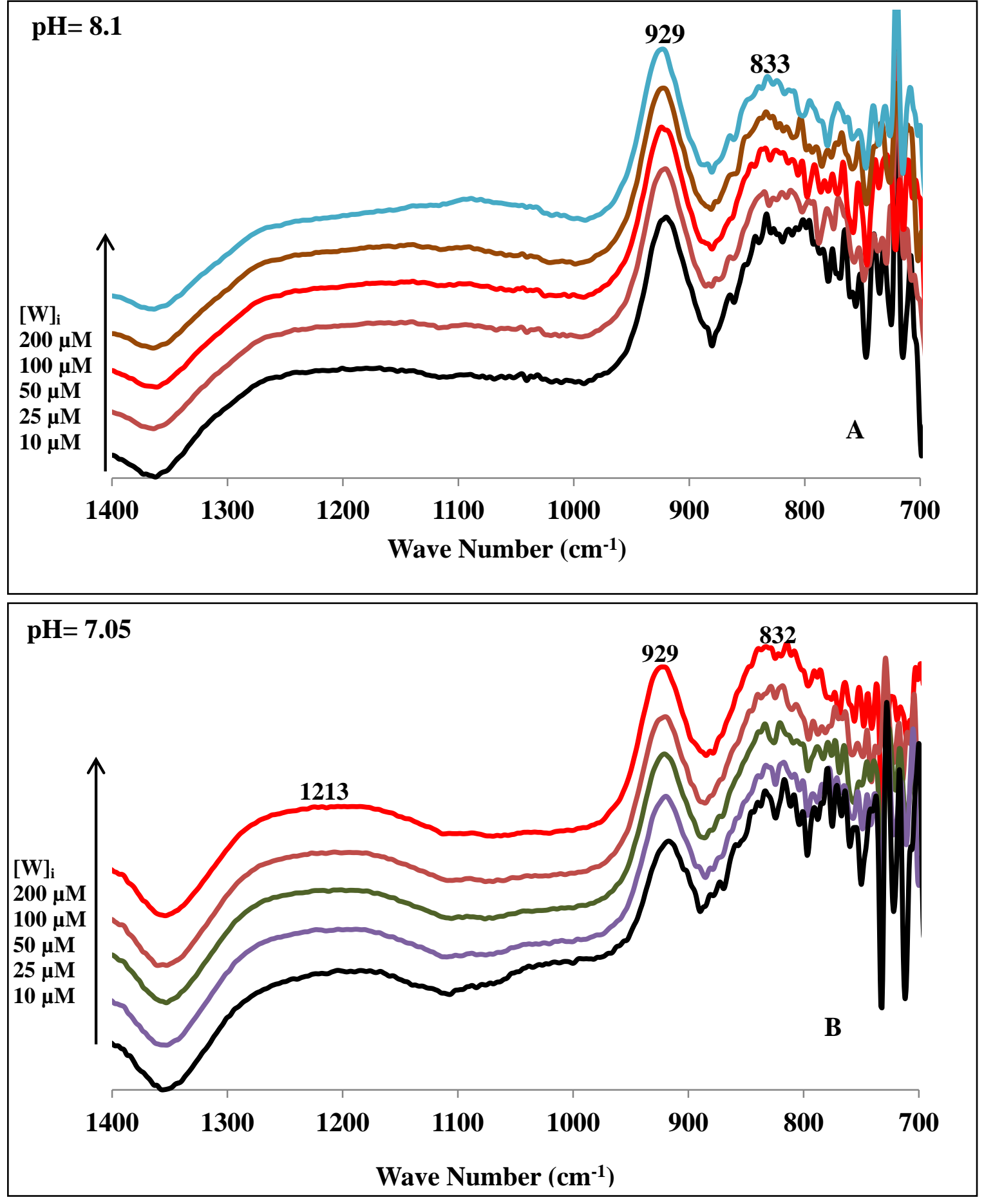

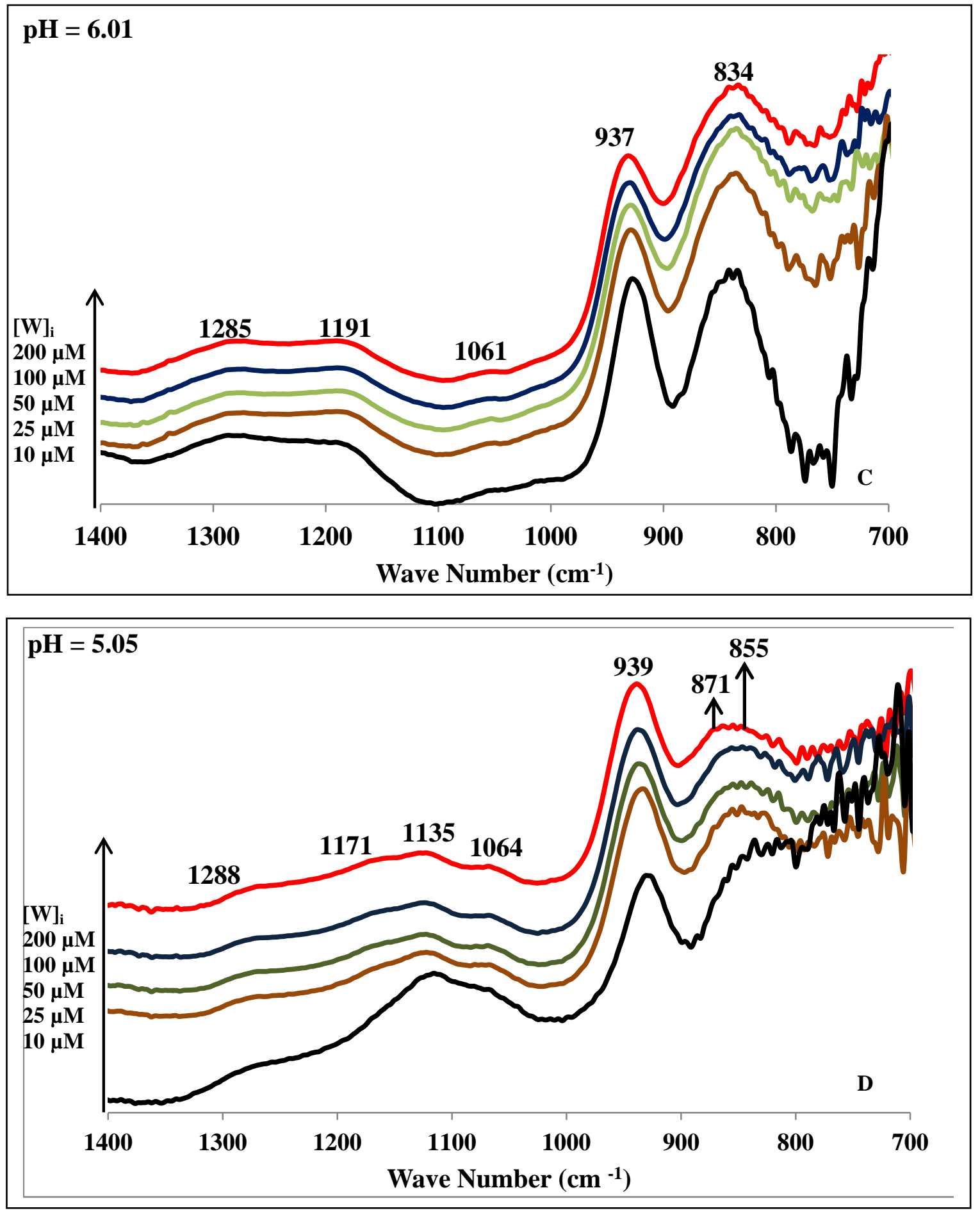
Figure 2
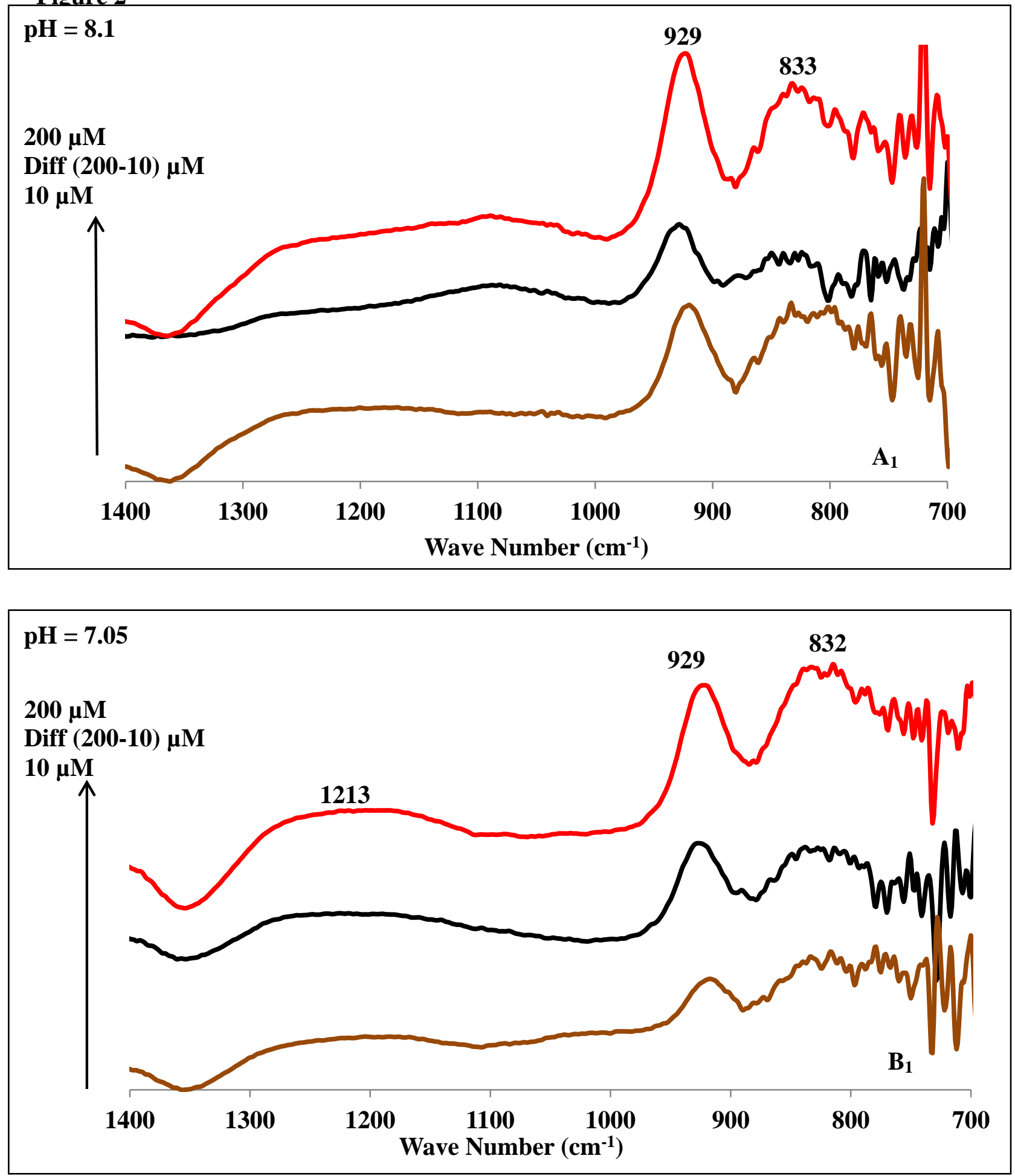

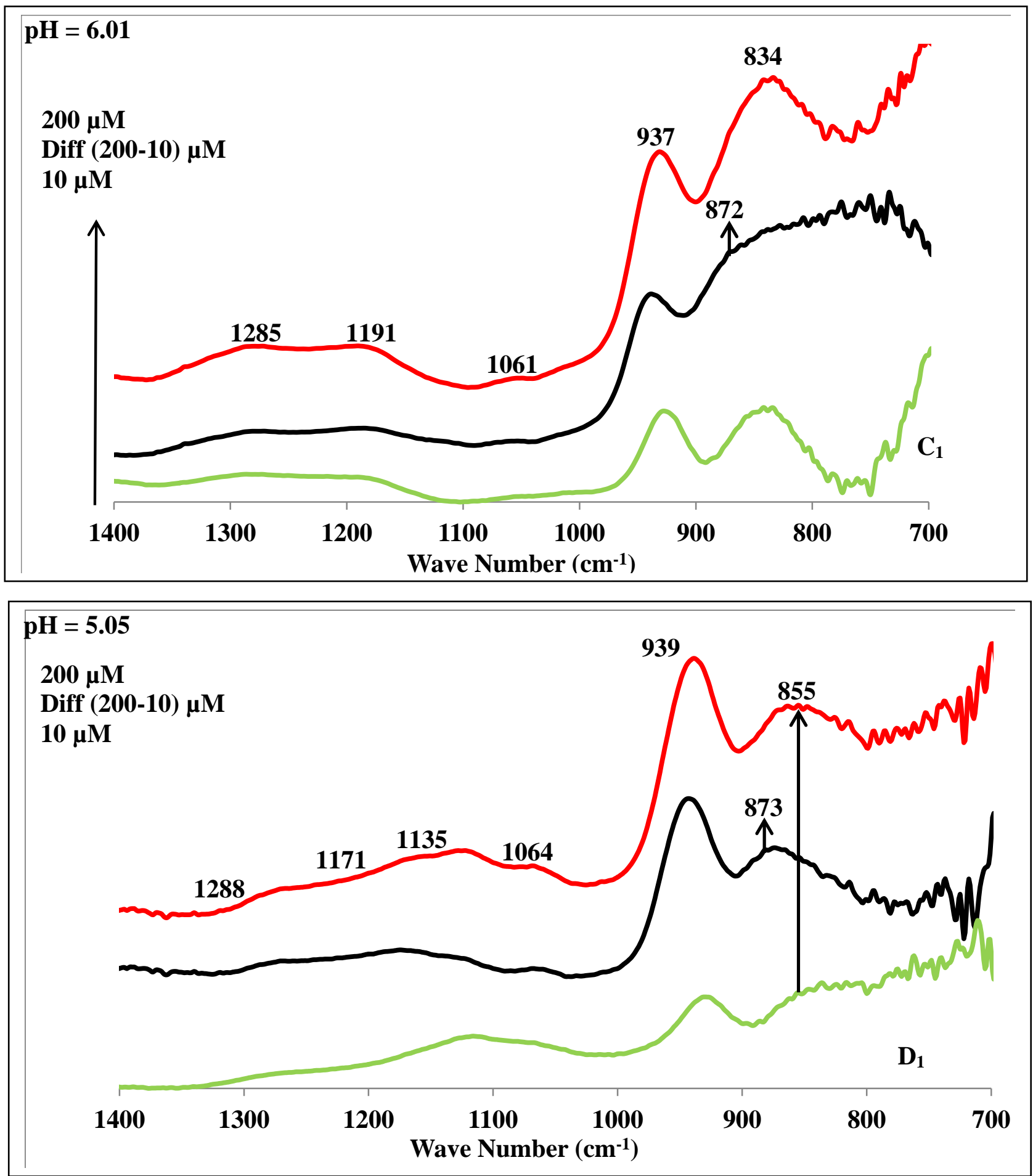
Figure 3
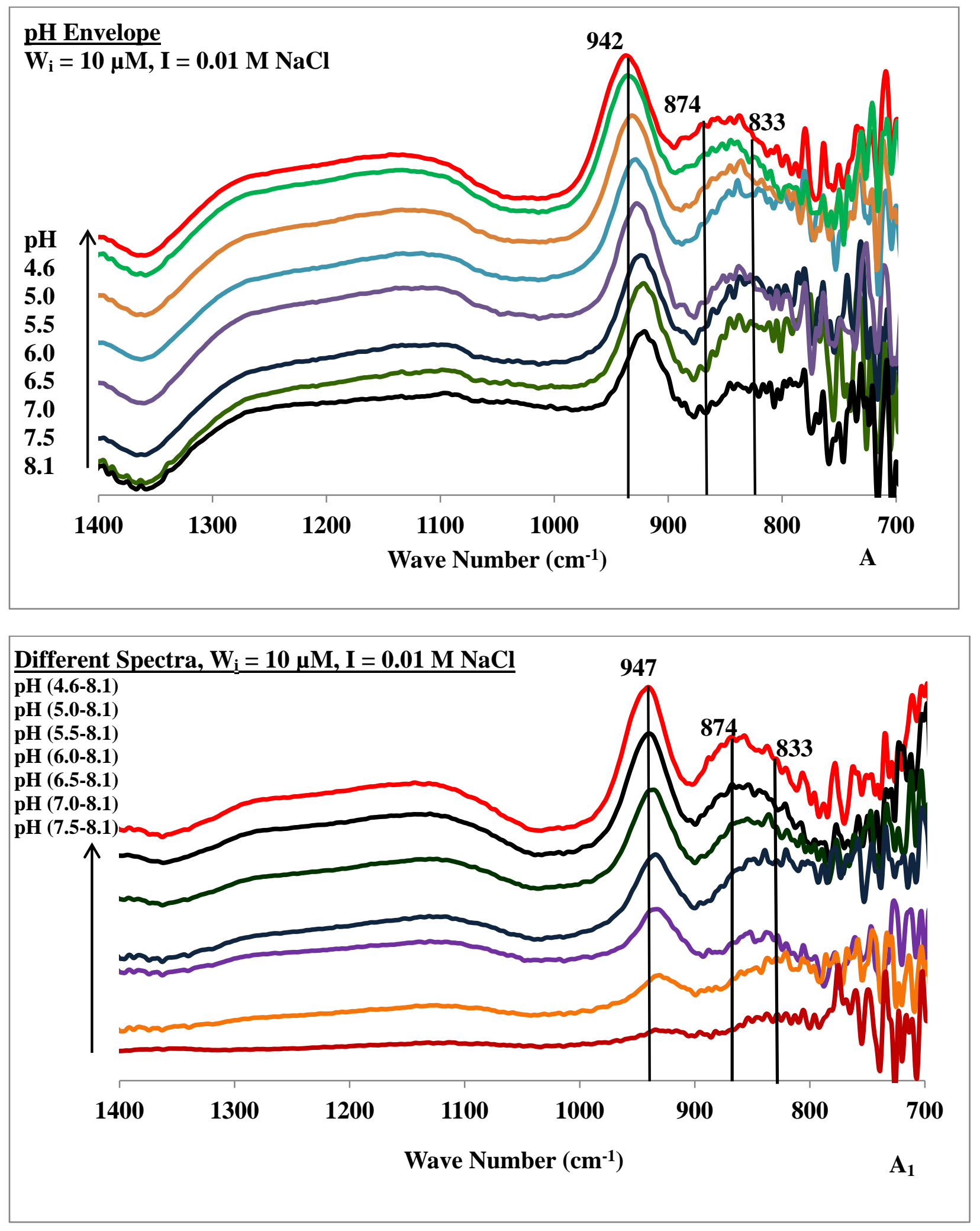


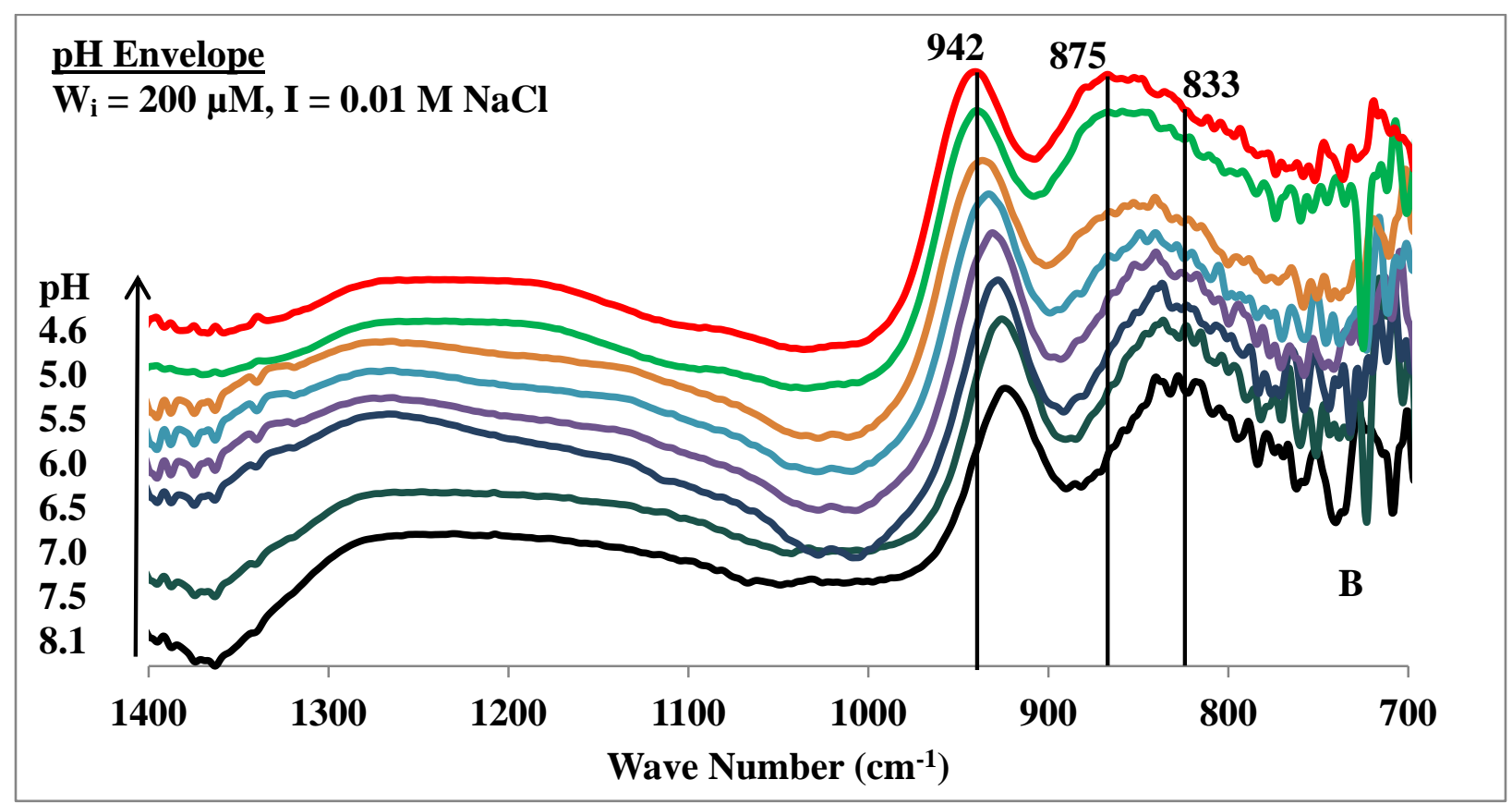

Different Spectra, $W_{i}=200 \mu M, I=0.01 \mathrm{M} \mathrm{NaCl}$

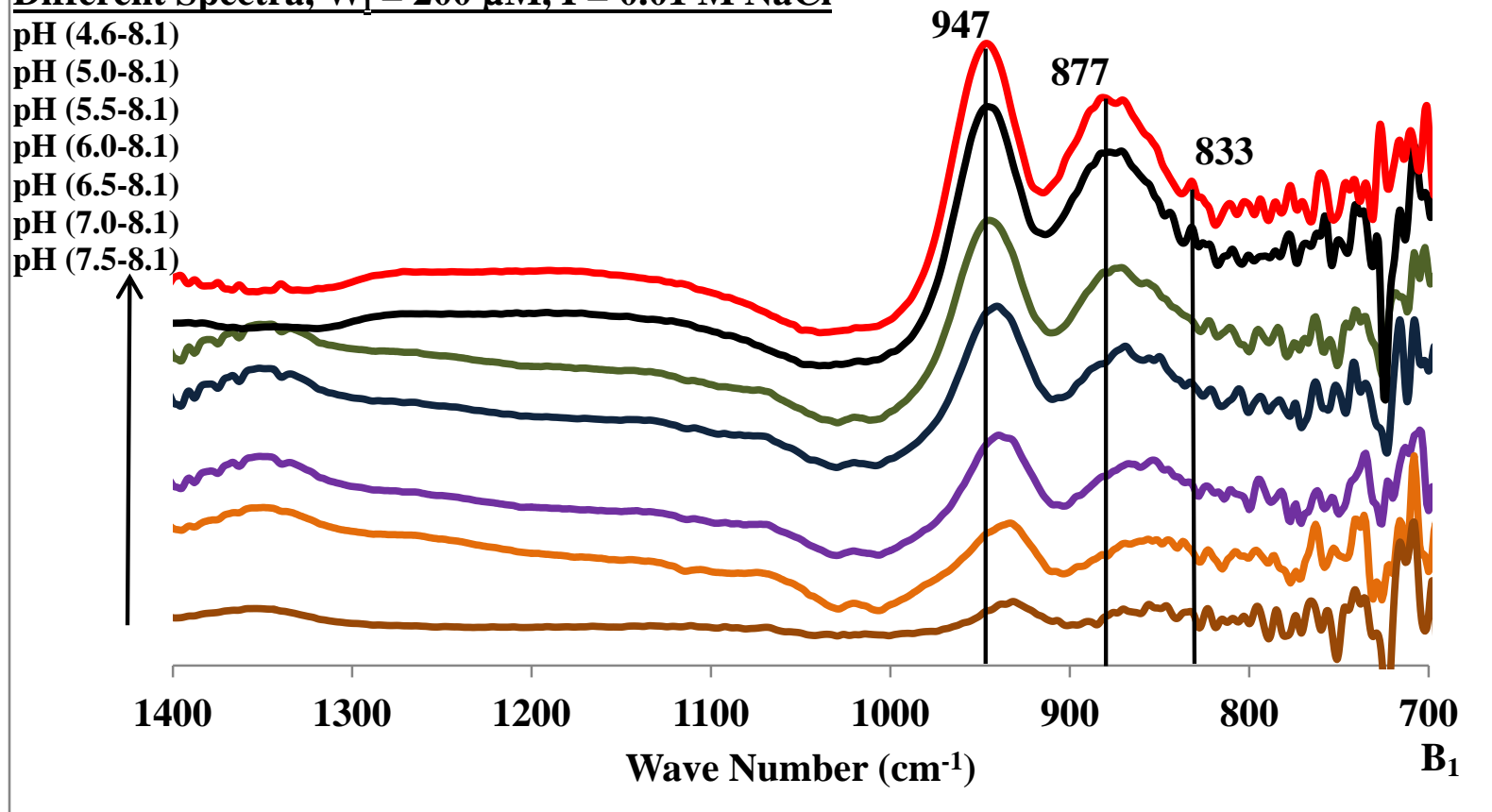

